\title{
Permafrost Thaw and Associated Settlement Hazard Onset Timing over the Qinghai-Tibet Engineering Corridor
}

\author{
Donglin Guo ${ }^{1} \cdot$ Jianqi Sun ${ }^{1}$
}

Published online: 22 December 2015

(c) The Author(s) 2015. This article is published with open access at Springerlink.com

\begin{abstract}
In permafrost areas, the timing of thermal surface settlement hazard onset is of great importance for the construction and maintenance of engineering facilities. Future permafrost thaw and the associated thermal settlement hazard onset timing in the Qinghai-Tibet engineering corridor (QTEC) were analyzed using high-resolution soil temperature data from the Community Land Model version 4 in combination with multiple model and scenario soil temperature data from the fifth phase of the Coupled Model Intercomparison Project (CMIP5). Compared to the standard frozen ground map for the Tibetan Plateau and ERAInterim data, a multimodel ensemble reproduces the extent of permafrost and soil temperature change in the QTEC at a $1 \mathrm{~m}$ depth from 1986-2005. Soil temperature and active layer thickness increase markedly during 2006-2099 using CMIP5 scenarios. By 2099, the ensemble mean soil temperature at $15 \mathrm{~m}$ depth will increase between 1.0 and $3.6{ }^{\circ} \mathrm{C}$ in the QTEC. Using crushed-rock revetments can delay the onset of thermal settlement hazard for colder permafrost areas by approximately 17 years in the worst case scenario of RCP8.5. Nearly one-third of the area of the QTEC exhibits settlement hazard as early as 2050, and half of this one-third of the area is traversed by the QinghaiTibet highway/railway, a situation that requires more planning and remedial attention. Simulated onsets of thermal settlement hazard correspond well to the observed soil temperature at $15 \mathrm{~m}$ depth for seven grid areas in the QETC, which to some extent indicates that these timing
\end{abstract}

Donglin Guo

guodl@mail.iap.ac.cn

1 Nansen-Zhu International Research Center, Institute of Atmospheric Physics, Chinese Academy of Sciences, Beijing 100029, China estimates are reasonable. This study suggests that climate model-based timing estimation of thermal settlement hazard onset is a valuable method, and that the results are worthy of consideration in engineering design and evaluation.

Keywords Hazard onset timing · Permafrost - QinghaiTibet railway . Thermal hazard

\section{Introduction}

Permafrost regions occupy approximately one-quarter of the land of the Northern Hemisphere and are widely distributed at high latitudes and regions of high altitude (Zhang et al. 1999). Changes in permafrost are likely to have a great impact on hydrology and water resources, ecosystem structure, the stability of infrastructure, and climate change (Nelson et al. 2002; Yang et al. 2010; Guo et al. 2011a, b; Koven et al. 2011). In addition to the concerns about the climatic, hydrological, and ecological effects of permafrost thaw, there is growing concern with regard to the hazard to human-made infrastructure caused by severe permafrost thaw. This is because permafrost regions tend to contain abundant natural resources, attracting a large number of people and the associated infrastructure development to these regions. For instance, the population of the Tibetan Plateau region has tripled over the last 45 years (Fu and Zheng 2000), accompanied by the rapid expansion of civil facilities and transportation networks (Cheng 2002). Other examples include the development of Prudhoe Bay in central Alaska's North Slope (Williams 1986) and the oil and gas fields in western Siberia (Seligman 2000). Permafrost degradation results in thaw settlement of the ground surface, most likely resulting 
in the disruption of human-made infrastructure, which is especially true for ice-rich permafrost regions. Examples include the collapse of a permafrost-underlain building in Norilsk in 1966, killing more than 20 people, as well as damage to more than 300 buildings and a power-generating station in Yakutsk, Russian, which was induced by thaw settlement (Nelson et al. 2002).

The Qinghai-Tibet highway and railway were completed in 1954 and 2006, respectively, both traversing the roof of the world-the Tibetan Plateau. The Qinghai-Tibet railway, with a construction cost of approximately USD 4 billion, stretches a length of $1,142 \mathrm{~km}$. Approximately $270 \mathrm{~km}$ of the railway is on warm permafrost [mean annual ground temperature above $-1.0^{\circ} \mathrm{C}$ (Wu and Zhang 2010)], $221 \mathrm{~km}$ on ice-rich permafrost, and $134 \mathrm{~km}$ on a mix of both (Cheng 2002; Qiu 2007). As a typical high-altitude permafrost, the permafrost of the Tibetan Plateau is more sensitive and thaws faster than high-latitude permafrost in response to climate warming (Guo and Wang 2011). Due to global warming, permafrost thaw on the Tibetan Plateau is likely to pose a potential threat to the stability of the Qinghai-Tibet highway and railway.

Construction of the Qinghai-Tibet highway in the 1950s did not take account of the effect of climate change in its engineering design, thus resulting in substantial thermal settlement hazards (Wu and Niu 2013). Although this issue has recently been considered in the design of the QinghaiTibet railway, concrete implementation has been limited because the overlapping influence of climate change and engineering thermal disturbance on permafrost cannot be separated and evaluated (Wu and Niu 2013). Both influences may constitute potential risks if the global climate continues to warm. Accordingly, an estimate of the timing of thermal settlement hazard onset in the Qinghai-Tibet engineering corridor (QTEC, the region that contains the Qinghai-Tibet highway and railway, pipelines, electric transmission lines, and so on) is of considerable importance for the maintenance of existing engineering facilities and the design of new ones.

With respect to the thermal dynamics of permafrostunderlain embankments, the impact of remedial measures on embankment stability, and real-time thermal settlement of embankments, previous studies have primarily focused on field monitoring (Wu and Tong 1995; Cheng 2003; Wu and Niu 2013; Ma et al. 2013; Liu et al. 2014). Wu and Zhang $(2008,2010)$ found that, on average, permafrost temperatures at $6 \mathrm{~m}$ depth have increased $0.43{ }^{\circ} \mathrm{C}$ from 1995 to 2006, and that active layer thickness has increased $0.9 \mathrm{~m}$ from 1995 to 2007. Based on observational data, $\mathrm{Wu}$ et al. (2003) indicated that the thermal settlement of an embankment increases along with a rise in the mean annual ground temperature. Ma et al. (2013) showed that the mean artificial permafrost table uplifts approximately 3.0 and
$2.7 \mathrm{~m}$ relative to the natural permafrost table in terms of crushed-rock embankment [contains a layer of crushedrock (Sun et al. 2008)] in cold and warm permafrost regions. In contrast, mean artificial permafrost table uplifts of approximately 1.63 and $-0.19 \mathrm{~m}$ occurred relative to the natural permafrost table for general embankments [similar to crushed-rock embankment but no crushed-rock layer (Sun et al. 2008)] in cold and warm permafrost regions. These studies not only reveal some realities, but also provide reliable observation data for validating the results of numerical simulation research.

Some studies have focused on predicting embankment settlement of the Qinghai-Tibet railway (Sun et al. 2004; Zhang et al. 2007; Zhang and Wu 2012; Ruan et al. 2014). Using a finite element analysis method, Sun et al. (2004) reported an embankment settlement of $25 \mathrm{~cm}$ from 2002 to 2030 with an assumption of rising air temperature of $0.02{ }^{\circ} \mathrm{C}$ year $^{-1}$. On the same assumption of an air temperature increase, Zhang et al. (2007) predicted that embankment settlement at Beiluhe is likely to reach $30 \mathrm{~cm}$ in the next 50 years. Ruan et al. (2014) employed a modified thermal settlement model to perform a risk zonation of thermal settlement hazard and found that high-risk areas by 2050 are the Chumarhe high plain, Wudaoliang, and Kaixinling areas. These studies provide key insights into the future thermal settlement hazard of embankments at some experimental sites and the relative hazard grade for different sections of the QTEC. This research considers the timing of future thermal settlement hazard onset for the entire grided area crossed by the QTEC, which appears in Figs. 1 and 4.

The objectives of the present study are to examine: (1) the future permafrost thaw situation along the QTEC in terms of soil temperature change at depths of 1 and $15 \mathrm{~m}$, active layer thickness change, and the timing of permafrost disappearance at depths of 0-8 $\mathrm{m}$; and (2) the time of onset of thermal settlement hazard in the QTEC. Both aspects were investigated using multimodel and multiscenario data from the fifth phase of the Coupled Model Intercomparison Project (CMIP5) (Taylor et al. 2012). A brief description of the data and methods is provided in Sect. 2, and the results and discussions are presented in Sect. 3. Possible uncertainties are addressed in Sect. 4, followed by a summary of the key findings of the study in Sect. 5 .

\section{Data and Methods}

In this study, simulation data from climate models and the land surface model, reanalysis data, the Tibetan Plateau permafrost map, the Circum-Arctic map of permafrost and ground ice conditions, and in situ observations of soil temperature were employed to analyze and validate the 


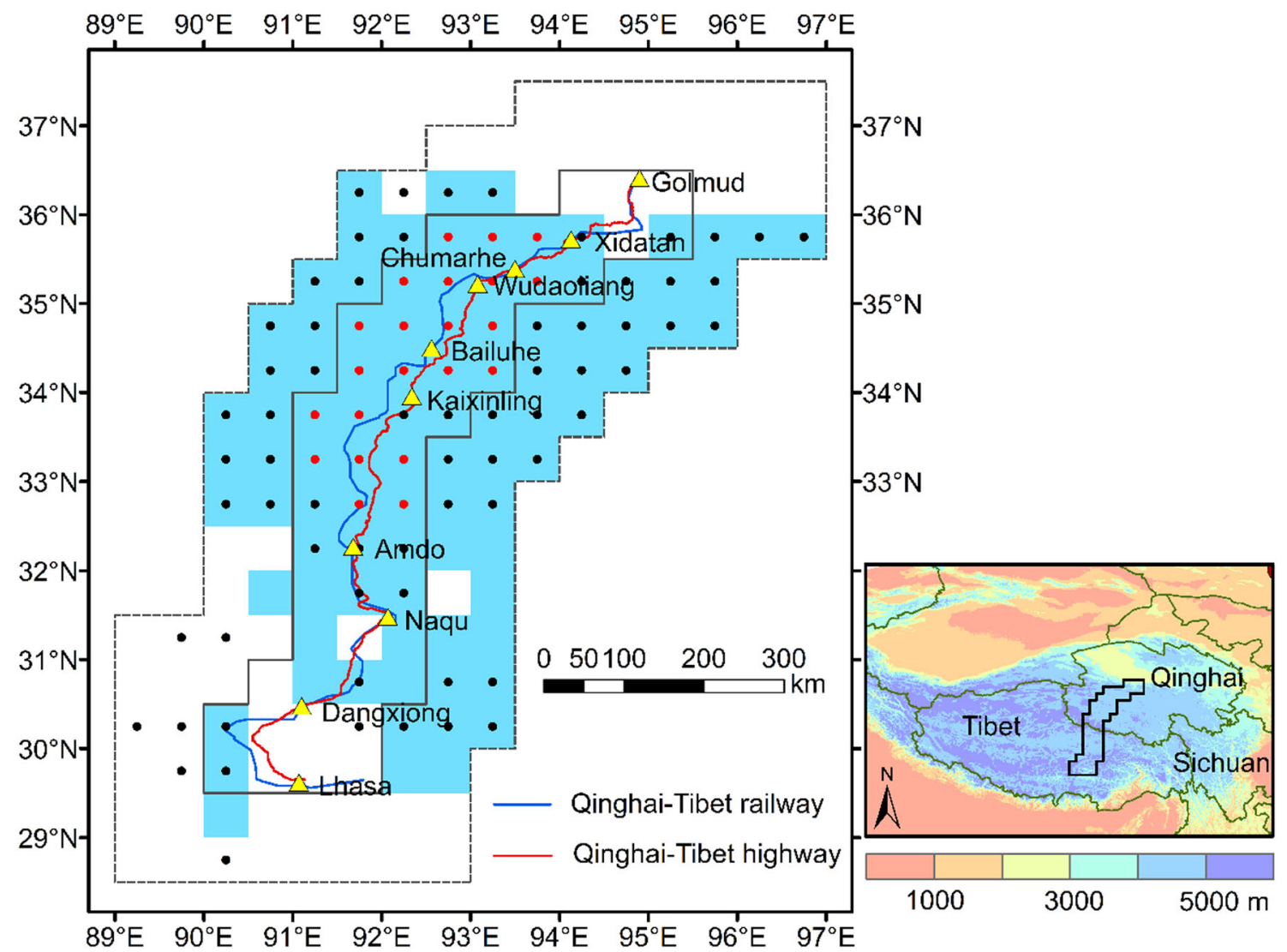

Fig. 1 Location of the Qinghai-Tibet engineering corridor (QTEC). The corridor is the area enclosed by the solid lines. Simulated presentday permafrost areas (grids) are marked in blue; permafrost areas (grids) from the Tibetan Plateau's frozen ground map are indicated by dots. Red dots represent the sites used to calculate the area-averaged time series of active layer thickness. The location of major cities and stations along the Qinghai-Tibet railway are denoted by yellow triangles and are identified by name. A wider corridor (the area indicated by the dashed lines) is also shown. The larger corridor is used to compare the narrower QTEC study area for research results to check the possible impact of coarse resolution of the climate models on this small-region study results. Meanwhile, a settlement index was also used to calculate the amount of thermal-induced settlement of the ground surface. The detailed descriptions about these data and methods are presented as follows.

\subsection{Data}

Historical and future soil temperature data were derived from CMIP5 simulations (Table 1). Data from only eight climate models (CCSM4, CESM1-CAM5, GFDL-ESM2g, MIROC5, MPI-ESM-LR, MRI-CGCM3, NorESM1-M, and NorESM1-ME) and three RCP (representative concentration pathway) scenarios (RCP2.6, RCP4.5, and RCP8.5) were used in this study. Limiting the study to these models was due to the following reasons: (1) some climate models do not provide soil temperature data; (2) models with a horizontal resolution larger than $2.5^{\circ}$ were not selected for this small-area study; and (3) models with a soil depth shallower than $6 \mathrm{~m}$ were eliminated due to the presence of a deep, active soil layer in the study region. Brief information about the eight climate models is provided in Table 1, and additional details regarding the CMIP5 simulation are available in Taylor et al. (2012). These data have been widely used to diagnose changes in permafrost in response to climate change in the future (Koven et al. 2013; Slater and Lawrence 2013).

In addition to the soil temperatures simulated by the CMIP5 climate models, a set of soil temperature data obtained from the Community Land Model version 4 (CLM4) driven by a set of reliable high-resolution atmospheric forcing data was also used (Table 1). Details of the forcing data and CLM4 simulation can be found in Guo and Wang (2013, 2014). Compared to the exiting Tibetan Plateau frozen ground map ( $\mathrm{Li}$ and Cheng 1996), the simulated data are able to produce a reasonable frozen ground distribution on the Tibetan Plateau. These data also closely compare to observed soil temperature data at the depths of 1 and $6 \mathrm{~m}$ (Guo and Wang 2013). Therefore, the 
Table 1 Details of the models and reanalysis data

\begin{tabular}{|c|c|c|c|c|c|c|}
\hline Model Name & $\begin{array}{l}\text { Resolution } \\
\left({ }^{\circ} \text { long } \times{ }^{\circ} \text { lat }\right)\end{array}$ & $\begin{array}{l}\text { Soil temperature } \\
\text { at } 1 \mathrm{~m} \text { depth }\left({ }^{\circ} \mathrm{C}\right)\end{array}$ & $\begin{array}{l}\text { Soil temperature at } \\
15 \mathrm{~m} \text { depth }\left({ }^{\circ} \mathrm{C}\right)\end{array}$ & $\begin{array}{l}\text { No. of soil } \\
\text { layers }\end{array}$ & $\begin{array}{l}\text { Depth of } \\
\text { soil }(\mathrm{m})\end{array}$ & Model reference \\
\hline CCSM4 & $0.9 \times 1.125$ & -2.37 & -2.52 & 15 & 35.18 & Gent et al. (2011) \\
\hline CESM1-CAM5 & $0.9 \times 1.125$ & -1.24 & -1.39 & 15 & 35.18 & James et al. (2013) \\
\hline GFDL-ESM2g & $2.0 \times 2.5$ & -5.05 & & 23 & 8.75 & Dunne et al. (2012) \\
\hline MIROC5 & $1.4 \times 1.4$ & -2.32 & & 6 & 9.0 & Watanabe et al. (2010) \\
\hline MPI-ESM-LR & $1.87 \times 1.87$ & -3.81 & & 5 & 6.98 & Giorgetta et al. (2013) \\
\hline MRI-CGCM3 & $1.12 \times 1.12$ & -6.55 & & 14 & 8.5 & Yukimoto et al. (2012) \\
\hline NorESM1-M & $1.87 \times 2.5$ & -1.81 & -1.99 & 15 & 35.18 & Bentsen et al. (2013) \\
\hline NorESM1-ME & $1.87 \times 2.5$ & -2.13 & -2.33 & 15 & 35.18 & Tjiputra et al. (2013) \\
\hline CLM4 & $0.23 \times 0.31$ & -2.14 & -2.44 & 15 & 35.18 & Oleson et al. (2010) \\
\hline ERA-Interim & $0.7 \times 0.7$ & -1.78 & & 4 & 2.89 & Dee et al. (2011) \\
\hline
\end{tabular}

Soil temperatures are the area-averaged values over the simulated present-day permafrost area in the QTEC. The depth of soil means the maximum depth having soil temperature data rather than the depth prescribed in the models

data were used as reference data to remove the systematic biases of soil temperature in climate models. The specific methods used to accomplish this correction are described in Sect. 2.2. The data are referred to as CLM4 data in this study.

Reanalysis data-the European Centre for MediumRange Weather Forecasts Re-Analysis Interim (ERA-Interim) described by Dee et al. (2011)—were also used to validate simulated soil temperature change in the historical period. The data have a horizontal resolution of $0.7^{\circ}$ longitude $\times 0.7^{\circ}$ latitude and cover a period from 1979 to 2014. Further details can be found in Table 1 . These data have been validated to be suitable for the permafrost region on the Tibetan Plateau (Qin et al. 2015).

The map of permafrost on the Tibetan Plateau developed by $\mathrm{Li}$ and Cheng (1996) was employed to validate the extent of simulated frozen ground in the QTEC in this study. These data are considered to be reliable (Zhao 2004; Ran et al. 2012), and they have been widely used to validate simulated permafrost distribution (Guo et al. 2012; Guo and Wang 2013).

Ground ice data were obtained from the Circum-Arctic map of permafrost and ground ice conditions (Brown et al. 1997; USNSIDC 2005). These data are provided in two formats-shapefile and grid-with three horizontal resolutions for the grid format. In this study, the grid format and $0.5^{\circ}$ longitude $\times 0.5^{\circ}$ latitude resolution were selected, and the horizontal resolution of $0.5^{\circ}$ longitude $\times 0.5^{\circ}$ latitude was used as a benchmark. All data, including climate model data, CLM4 data, reanalysis data, and permafrost map data, were interpolated into this common resolution for homogenous comparison.

In situ observations of soil temperature at a depth of $15 \mathrm{~m}$ were obtained from $\mathrm{Wu}$ et al. (2010) and Liu et al. (2014). Stations with observation times after 1986 were selected to represent the present-day soil thermal conditions. A total of 20 stations were used to validate the results of our surface settlement hazard onset timing simulation. Because the simulated results are mean values for each grid, we compared the simulated results with station observations derived from the corresponding grid cells. If a grid cell contains more than one station, the mean of the station observations was calculated to represent the value of this grid cell.

\subsection{Methods}

By considering that both ground ice and active layer change are the most important dynamic factors of the permafrost ground surface, Nelson et al. (2002) established a method of calculating the settlement index $\left(I_{s}\right)$, as follows:

$I_{s}=\Delta Z_{a l} \cdot V_{\text {ice }}$

where $\Delta Z_{a l}$ is the relative increase of active layer thickness; and $V_{i c e}$ is ground ice content, with a unit of volumetric proportion. A concomitant assumption in Eq. 1 is that the liquid water yielded by ground ice melting can be drained from a study site and that the related thaw settlement of the ground surface is proportional to the thickness of the melted ice.

As defined in Eq. 1, $I_{s}$ is a dimensionless index that cannot express a certain amount of thermal settlement. However, an amount of settlement is needed to predict the timing of thermal settlement hazard onset. In this study, the relative increase in Eq. 1 is modified to the actual amount of increase in the active layer thickness, with a unit of meters. In this case, index $I_{s}$ denotes an amount of surface settlement, and with a unit of meters. This is a fair modification because the physical implication of the index is 
completely the same as the original one, which is also implied in Ruan et al. (2014). In the present study, the required variable of layer thickness increase was calculated using the soil temperature from the climate models, and the ground ice content was obtained from the map of permafrost and ground ice conditions.

Previous studies indicate that the Qinghai-Tibet railway could operate normally when the degree of surface settlement is less than $30 \mathrm{~cm}$ (Zhang et al. 2007; Wang et al. 2010). Therefore, a settlement amount of $30 \mathrm{~cm}$ is taken as a criterion for the onset of settlement hazard. When calculating the timing of settlement hazard onset, it is assumed that if in three consecutive years the settlement amount exceeded $30 \mathrm{~cm}$, the first year of these 3 years can be considered as the time of hazard onset. The 3 year requirement is made to avoid the influence of short-term climate variations on the calculation of hazard timing.

To remove any systematic biases in the soil temperature of climate models, yearly anomalies of soil temperature, relative to the 1986-2005 average, were first calculated, and these anomalies were then added to the averages of the CLM4 data for 1986-2005. This method has been successfully applied to correct systematic biases of a climate model (Slater and Lawrence 2013), but it is underpinned by an assumption that these biases do not change with time.

To calculate the permafrost area and active layer thickness, soil temperature layers were linearly interpolated to evenly spaced layers of $0.1 \mathrm{~m}$ depth. Permafrost ground was identified as the area where at least one layer among the upper $8 \mathrm{~m}$ of soil has a monthly soil temperature below $0{ }^{\circ} \mathrm{C}$ for 24 consecutive months. The active layer thickness was calculated as the maximum depth of thaw over the course of the year. In the process of calculating a time series of active layer thickness, if the active layer thickness of the prescribed grid cells exceeds the maximum soil layer depth of the climate model in a certain future year, this year and the ensuing years were eliminated. Similarly, when calculating the time of settlement hazard onset, if the time cannot be detected for some grid cells due to a shallow soil layer depth of the climate model, these grid cells were removed.

\section{Results and Discussion}

The results and associated discussions are presented with regard to two parts in this section. They are permafrost thaw and settlement hazard timing, respectively.

\subsection{Permafrost Thaw}

As shown in Fig. 1, the simulated present-day (1986-2005 average) ensemble mean permafrost area, which is taken as the "present-day permafrost area" in this study, shows good agreement with those from the Plateau's frozen ground map. Only 5 of 41 simulated grid cells show disagreement with the map, and these are situated in the warm permafrost region in the southern QTEC. Li and Cheng (1996) showed that small-area, isolated permafrost sites are present in the warm permafrost region but the model could not capture these permafrost areas due to its coarse resolution.

Area-averaged changes in soil temperature at a depth of 1 and $15 \mathrm{~m}$ in the present-day permafrost area in the QTEC are shown in Fig. 2a, b. The time series of the CLM4 data are in close agreement with that from the ERA-Interim dataset during the period from 1986 to 2005, with a correlation coefficient of 0.57 and a significance level that exceeds $99 \%$. For the same period, the simulated ensemble mean soil temperature at $1 \mathrm{~m}$ depth also fits well with the average of ERA-Interim and CLM4 data, with a correlation coefficient of 0.49 , and a significance level greater than $95 \%$. By 2099, the ensemble mean soil temperature at $1 \mathrm{~m}$ depth will increase by $1.0^{\circ} \mathrm{C}$ (RCP2.6), $1.9^{\circ} \mathrm{C}$ (RCP4.5), and $4.5^{\circ} \mathrm{C}$ (RCP8.5) in the present-day permafrost area in the QTEC, although a wide range of temperature was found across the climate models. The soil temperature change, as averaged over the wide corridor, has a rather close range across the models to that in the narrow corridor under RCP8.5 (Fig. 2a). This indicates that despite being based on coarse resolution data from climate models, this narrow corridor is an appropriate area in terms of size for the present study.

The mean annual ground temperature (MAGT), defined as the soil temperature at a depth of zero annual amplitude, is thought to be a good indicator of the response of permafrost to long-term climate change (Xu et al. 2010). On the Tibetan Plateau, MAGT is usually consistent with the soil temperature at a depth of $15 \mathrm{~m}$ (Wu and Zhang 2010). Therefore, the soil temperature change at $15 \mathrm{~m}$ depth is also given. As shown in Fig. 2b, the simulated ensemble mean soil temperature at $15 \mathrm{~m}$ depth is similar to that based on CLM4 data during the period 1986-2005, with a correlation coefficient of 0.89 , and a significance level of over $99 \%$. Compared to the soil temperature change at a depth of $1 \mathrm{~m}$, the soil temperature at a depth of $15 \mathrm{~m}$ has a distinctly small amplitude in response to future climate change. By 2099, the increase in ensemble mean soil temperature will be $1.0{ }^{\circ} \mathrm{C}(\mathrm{RCP} 2.6), 1.9^{\circ} \mathrm{C}(\mathrm{RCP} 4.5)$, and $3.6{ }^{\circ} \mathrm{C}(\mathrm{RCP} 8.5)$ in the present-day permafrost area in the QTEC.

In response to rising soil temperature, the active layer thickness (ALT) shows a significant increase during both the historical and future periods (Fig. 3). For the historical period of 1986-2005, the ensemble mean active layer thickness has a trend of $0.15 \mathrm{~m}$ decade $^{-1}$, which is close to 
(a)

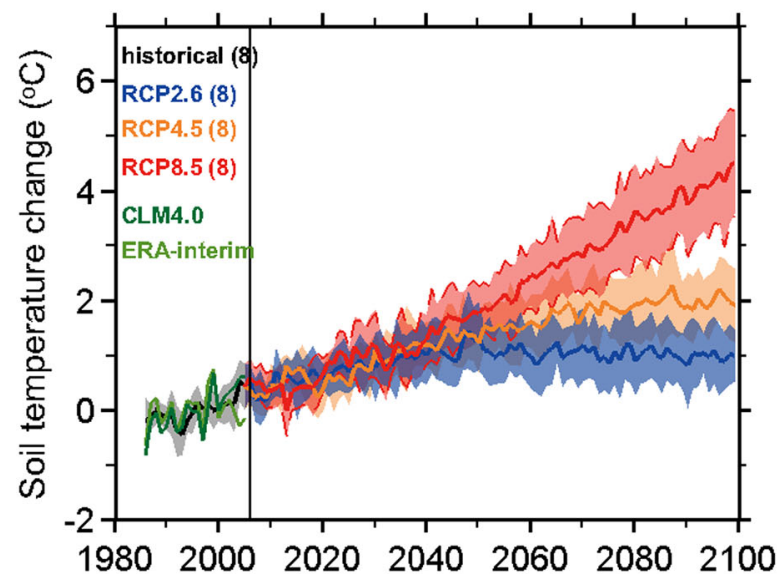

(b)

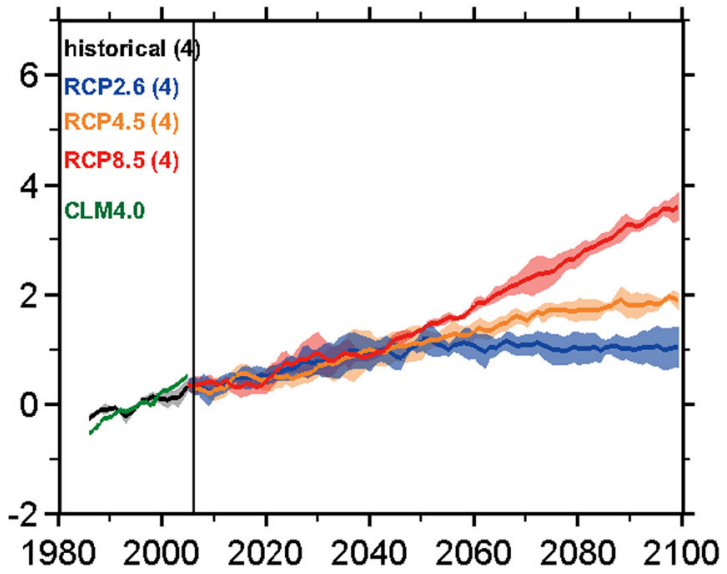

Fig. 2 Area-averaged changes in soil temperature at a depth of $1 \mathrm{~m}$ (a) and $15 \mathrm{~m}$ (b). These figures are averaged over the simulated present-day permafrost area in the QTEC during the period 1986-2099, relative to the period 1986-2005. The number of models used for the historical and each RCP estimate is shown in parentheses.

the trend of $0.13 \mathrm{~m}$ decade $^{-1}$ based on CLM4 data. Compared to soil temperature, the change in the active layer thickness appears to be more sensitive to climate warming in the future. By 2060, the ensemble mean active layer thickness will increase by $0.98 \mathrm{~m}$ (RCP2.6), $1.65 \mathrm{~m}$ (RCP4.5), and $4.30 \mathrm{~m}$ (RCP8.5) in the present-day permafrost area in the QTEC, despite a large range across the different climate models.

To illustrate the timing of permafrost disappearance and settlement hazard onset of each grid cell in the QTEC, we first numbered each grid (Fig. 4); the seven grid cells with observed MAGTs are labeled in bold color. As shown in Fig. 5, for the grids with a permafrost disappearance time

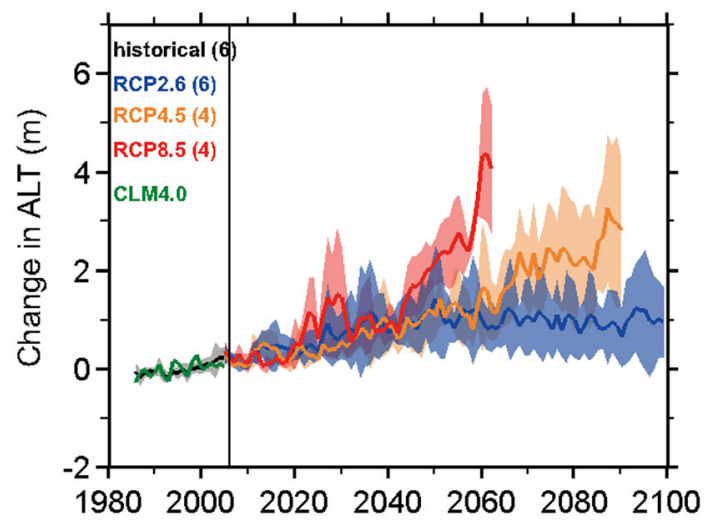

Fig. 3 Area-averaged changes in active layer thickness (ALT). These changes are averaged over the permafrost area that is indicated by red dots in Fig. 1 during the period 1986-2099, relative to the period 1986-2005. The number of models used for the historical and each RCP estimate is shown in parentheses. Shaded areas represent one standard deviation across models
Shaded areas represent one standard deviation across models. In a, the red lines at the edge of the shaded areas of the RCP8.5 scenario represent the range of soil temperature change in the wide corridor shown in Fig. 1

later than the near-term (2006-2036) under the RCP2.6 scenario, the permafrost disappearance time advances with increasing RCPs (from 2.6 to 8.5). However, for the grids

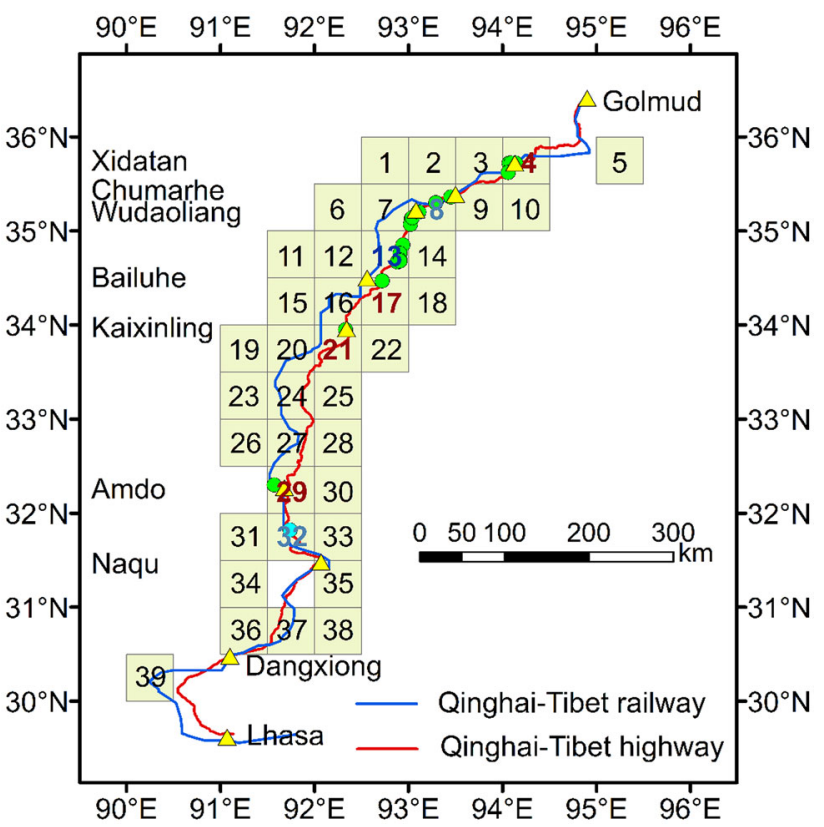

Fig. 4 Grid cells containing permafrost in the QTEC in 2005. The locations of major cities and stations along the Qinghai-Tibet railway are denoted by yellow triangles and are indicated by their name (some names are placed at the left margin of the figure to avoid the overlay of information). Green dots represent observation stations where MAGTs are available to indicate the thermal properties of permafrost. Bold red numbering $(4,17,21,29)$ refers to a grid with a MAGT $>-1{ }^{\circ} \mathrm{C}$, light blue $(8,32)$ refers to a grid with a MAGT $<-1$ but $>-1.5^{\circ} \mathrm{C}$, and dark blue (13) refers to a grid with a MAGT $<-1.5{ }^{\circ} \mathrm{C}$ 

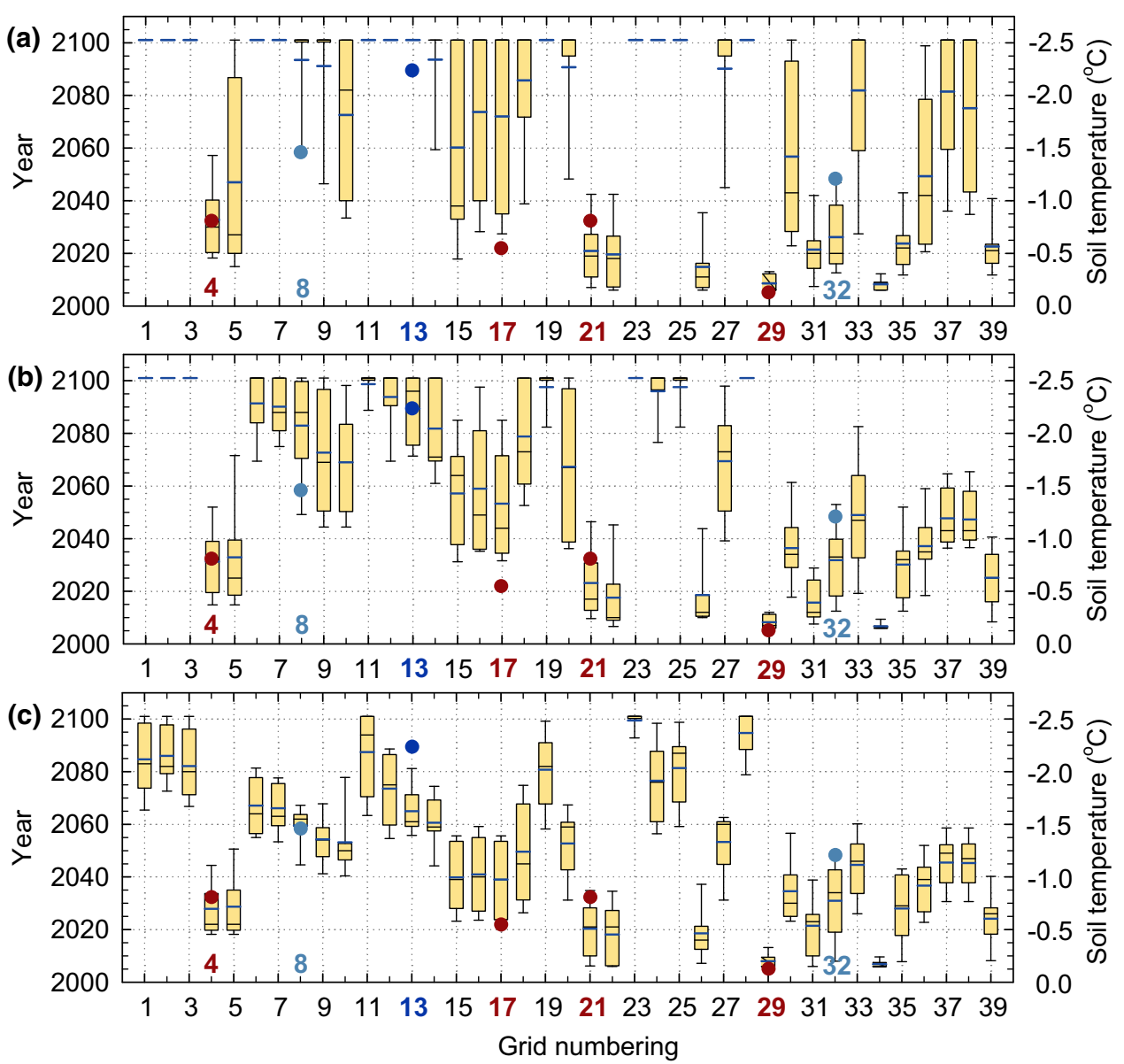

Fig. 5 Timing of the disappearance of permafrost (boxplot, year) at the depth of $0-8 \mathrm{~m}$ for each corresponding grid cell shown in Fig. 4 under RCP2.6 (a), RCP4.5 (b), and RCP8.5 (c), relative to the situation in 2005 . The observed soil temperature $\left(\right.$ dots, $\left.{ }^{\circ} \mathrm{C}\right)$ at a depth of $15 \mathrm{~m}$ in seven grids is also presented for comparison. Box and whiskers plots indicate the 10th and 90th percentiles (whiskers), 25th and 75th percentiles (box ends), median (thin solid black middle line), and means (thick solid dark blue middle line). Red numbers and dot

with a permafrost disappearance time within the near-term under the RCP2.6 scenario, the permafrost disappearance time shows only small changes. This is because the soil temperature increases are similar during the near-term for the RCP2.6, RCP4.5, and RCP8.5 scenarios (Fig. 2). Under the RCP2.6 scenario, 12 of the 39 grid cells have an ensemble mean timing earlier than 2050. However, the number increases to 16 and 20 under the RCP4.5 and RCP8.5 scenarios, respectively. These grid cells include Xidatan, southern Bailuhe, Kaixinling, Amdo, and the Naqu area.

There are no direct observations with respect to the existence of permafrost. Nonetheless, as permafrost disappearance times are closely related to its thermal properties, the above estimated times are compared to the observed soil temperature in the corresponding grids. The estimated times correspond well with the soil temperature refer to a grid with a MAGT $>-1{ }^{\circ} \mathrm{C}$, light blue refers to a grid with a MAGT $<-1$ but $>-1.5^{\circ} \mathrm{C}$, and dark blue refers to a grid with a MAGT $<-1.5^{\circ} \mathrm{C}$. Because the study covers the time period from the present day to 2100 , a grid cell with a permafrost disappearance time later than 2100 was assigned an artificial value of 2101 . In this case, the downward whiskers and box end value and the means of these grid cells, as shown, are smaller than the true size

observations at $15 \mathrm{~m}$ depth in the seven grid cells, with the correlation coefficient reaching 0.83 and statistical significance exceeding $95 \%$. This indicates that the estimated results are meaningful.

\subsection{Settlement Hazard Timing}

Figure 6 provides the onset time of thermal settlement hazard of each grid cell in the QTEC based on RCP2.6, RCP4.5, and RCP8.5 simulations. Similar to the timing of permafrost disappearance, the timings for grid cells with hazard onset later than the near-term notably advance with increasing RCP (from 2.6 to 8.5). But for the grid cells with a hazard onset time within the near-term, the timings show little change. Under the RCP2.6 scenario, 14 of 39 grid cells have an ensemble mean time earlier than 2050 . However, the number increases to 16 and 24 under the 
Fig. 6 Same as Fig. 5, except for onset timing of thermal surface settlement hazard in each QTEC grid cell. Some box and whiskers plots, such as those for grid number 29, do not show whiskers. This is because these whiskers cannot be calculated due to a lack of samples
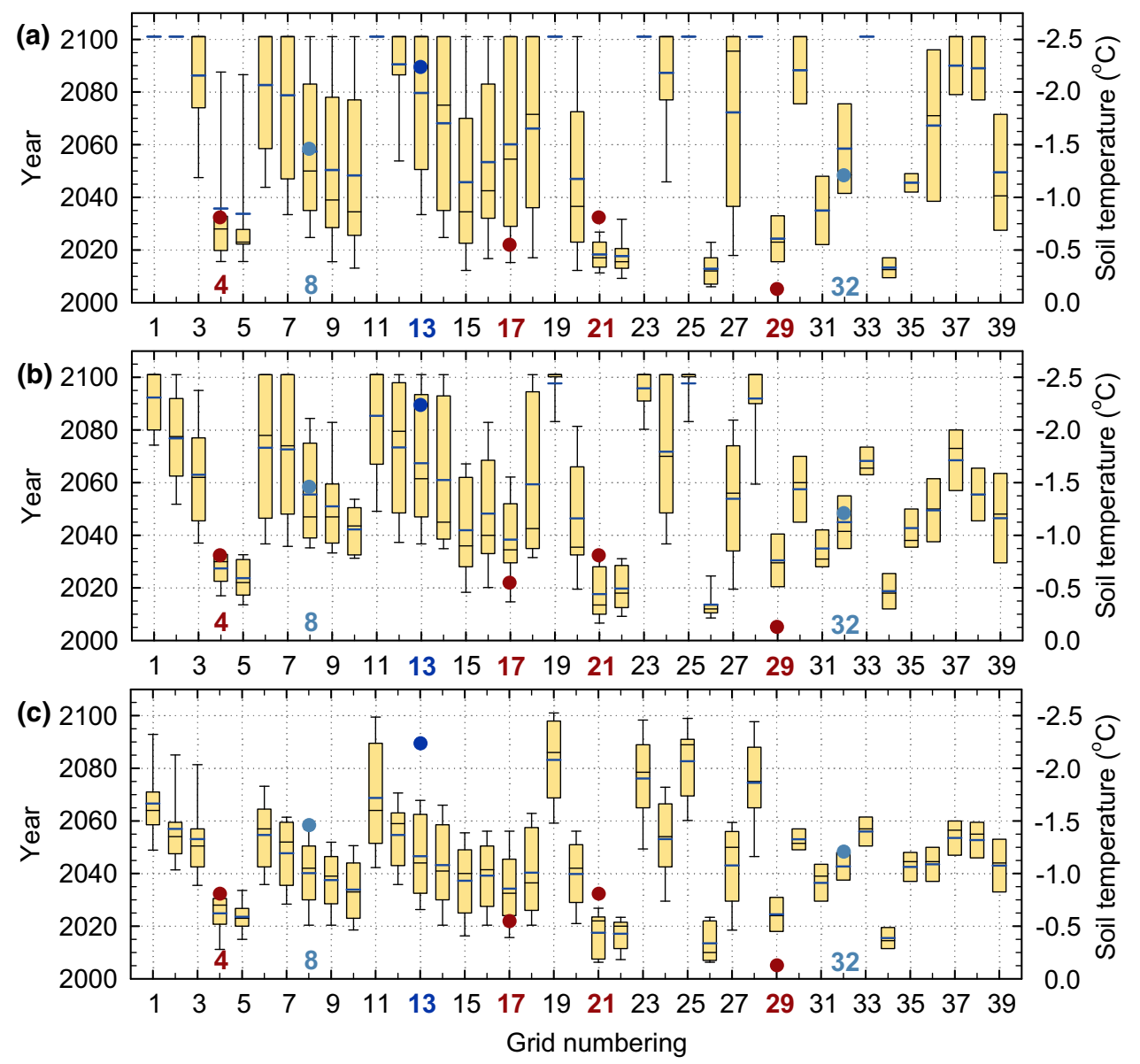

RCP4.5 and RCP8.5 scenarios, respectively. Notably, a wide range of results is found across the climate models.

$\mathrm{Wu}$ et al. (2003) found that the thaw settlement of embankments is closely related to MAGT, with large thaw settlement associated with high MAGT. For validation of this relationship, we performed a comparison between the estimated timings and observed MAGTs at the seven grid cells and find a good relationship between them, with a correlation coefficient of 0.82 , which exceeds the $95 \%$ significance level.

These results present settlement hazard induced by climate warming alone. Practically, some remedial measures could be applied to the Qinghai-Tibet highway/railway, including embankments, paving thermosiphons and ventiducts, and crushed-rock structure embankments. These measures effectively accommodate the impact of climate warming on the stability of an embankment (Lai et al. 2003; Zhang et al. 2005; Ma et al. 2012). Ma et al. (2013) indicate that crushed-rock embankments can cause natural permafrost table uplift of approximately 3.0 and $2.7 \mathrm{~m}$ in cold and warm permafrost regions, and that general embankments are also helpful to uplift the permafrost table, but with a relative small effect. To estimate the realistic onset timing of settlement hazard that combines the thermal role and remedial effect, we assume that climate warming needs to first offset the natural permafrost table uplift caused by remedial measures and then further yield warming-induced settlement. This is a fair assumption because settlement does not occur in the initial stage due to the natural permafrost table uplift occurring in an ice-free embankment. In our calculations, we used the largest natural permafrost table uplift of $3.0 \mathrm{~m}$ from Ma et al. (2013), which means that the estimated timings are the latest onset limit.

The onset timing of the thermal surface settlement hazard considering remedial measures for each grid cell in the QTEC is shown in Fig. 7, where thermal settlement hazard delay after remedial measures are considered. Under the RCP8.5 scenario, in terms of the grid cell mean, the onset time is approximately delayed by 14 years. The delay is much greater for relatively colder permafrost (grid numbers 1-28) than warmer permafrost (grid numbers 29-39), with values of 17 and 6 years, respectively (Fig. 7c). Among a total of 39 grid cells, 8, 10, and 12 cells have ensemble mean timings prior to 2050 under the RCP2.6, RCP4.5, and RCP8.5 scenarios, respectively. 
Fig. 7 Same as Fig. 5, except for onset timing of the thermal surface settlement hazard in combination with remedial measures in each QTEC grid cell. Some box and whiskers plots, such as those for grid number 29, do not show whiskers. This is because these whiskers cannot be calculated due to a lack of samples
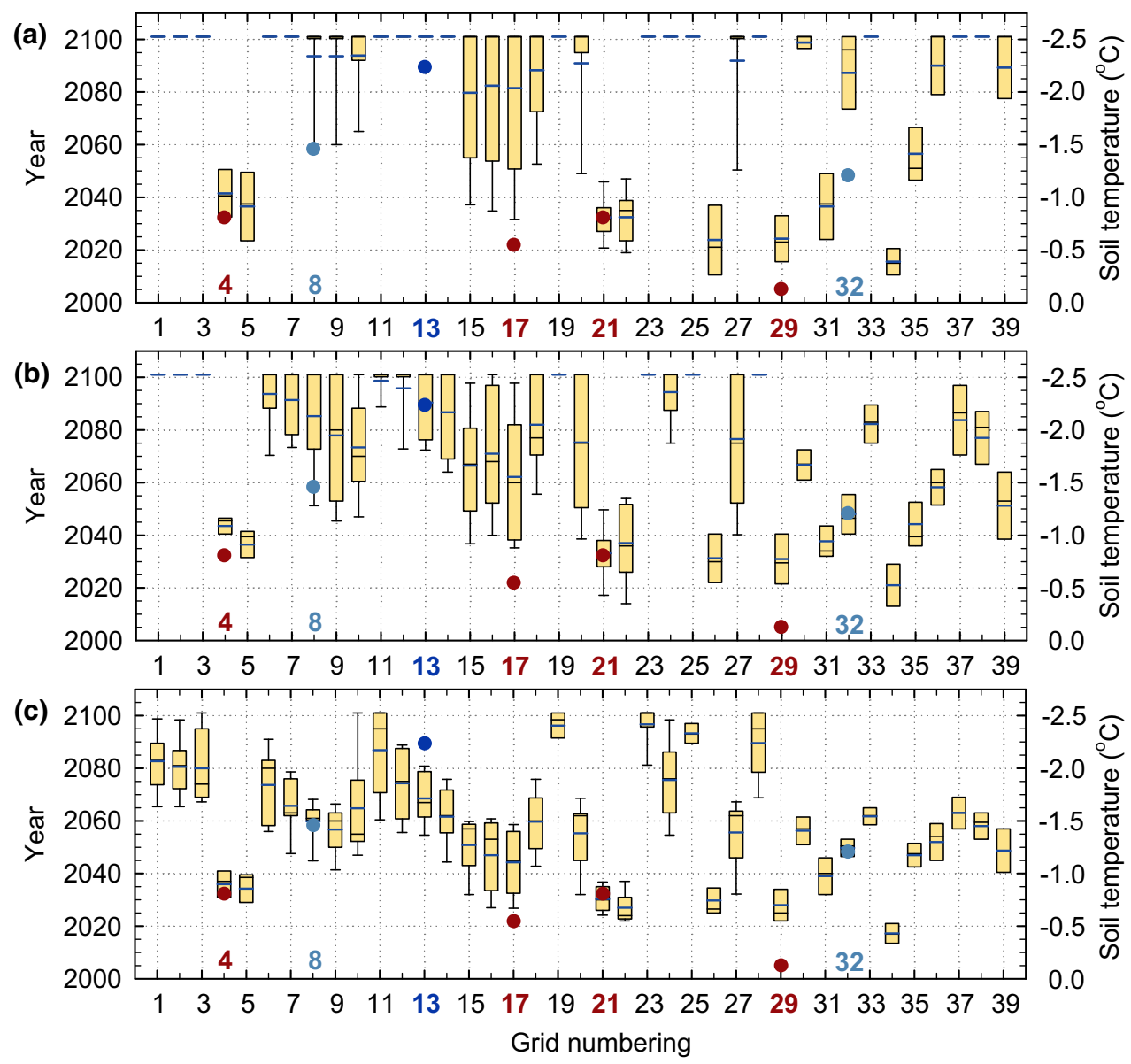

These include Xidatan, southern Bailuhe, Kaixinling, and Amdo area. Moreover, the Qinghai-Tibet highway/railway stretches over half of these 12 grid cells, a situation that should be given more attention in the future.

Zhang et al. (2005) indicates that a crushed-rock embankment is able to counteract the influences of climate warming on embankment engineering under the scenario of air temperature increases of $2.6^{\circ} \mathrm{C}$ by 2050 . The present results show that a few grid cells may still experience thermal settlement hazard. But the two results are not contradictory in terms of the individual characteristics of these grid cells, such as a possible greater than $2.6{ }^{\circ} \mathrm{C}$ warming, warmer permafrost, or more ground ice.

Similar to the settlement hazard induced by climate warming alone, the estimated hazard timing considering remedial measures corresponds well to the observed soil temperature at $15 \mathrm{~m}$ depth in the seven grid cells. The correlation coefficient is 0.82 , exceeding the $95 \%$ significance level, which to some extent indicates the validity of these timing estimates.

The results shown in Fig. 7 are the latest onset limit because we used the largest natural permafrost table uplift caused by remedial measures in our calculation of settlement hazard onset in all grid cells. Therefore, for those grid cells with a general embankment, the timing of actual settlement hazard onset should be earlier than that shown in Fig. 7, but later than that shown in Fig. 6.

\section{Discussion of Possible Uncertainties}

Assessing the time of onset of a warming-induced engineering hazard is difficult but very necessary for engineering design and maintenance. The present study attempts to estimate the timing of thermal settlement hazard onset in the QTEC by using multi-model and multiscenario soil temperature data from CMIP5 climate models. The related possible sources of uncertainty are discussed in this section.

The present study utilizes ground ice data from the map of permafrost and ground ice conditions. These data are perhaps the best available data of ground ice distribution at present and are highly appropriate for a hemisphere-scale study (Nelson et al. 2002). But they may be less appropriate for a small-region study, especially for the Tibetan Plateau, which is characterized by sparse observations. In addition, ground 
ice is a key factor accounting for the time of thermal settlement hazard onset (Eq. 1). Thus the use of these data in the QTEC may be a primary source of uncertainty in the present study. We hope that more observational studies with respect to ground ice are carried out and that the related data are released to promote further studies.

Another source of uncertainty is the coarse horizontal resolution of the soil temperature data from the climate models, with a range from $0.9^{\circ} \times 1.125^{\circ}$ to $2.0^{\circ} \times 2.5^{\circ}$. This coarse resolution provides less regional details about climate change in the QTEC and results in several adjacent grid cells in the QTEC having the same climate change trajectory. The difference in climate change between these adjacent grid cells cannot be identified, thus contributing to some extent to the uncertainty of the estimated timing of individual grid cells. The dynamical downscaling method, based on regional climate modeling, can largely improve the horizontal resolution of the data based on climate models (Gao et al. 2013; Guo and Wang 2016). Therefore, this method is expected to be applicable in future studies on this issue.

Existing studies indicate that embankment settlement is related to soil particle size, topography, and local environmental conditions (Liu et al. 2006). For instance, coarse soil particles are usually advantageous for preventing the settlement of an embankment compared to fine soil particles. However, the present study does not account for these factors, which may also contribute to the uncertainties in estimation. Such factors should be considered in future studies.

\section{Conclusion}

The timing of the onset of thermal settlement hazard in the QTEC under RCP2.6, RCP4.5, and RCP8.5 scenarios was investigated using multimodel soil temperature output from CMIP5 models at the regional scale. A multimodel ensemble captures accurately the extent of observed permafrost in the Qinghai-Tibet engineering corridor. Simulated soil temperature change at a depth of $1 \mathrm{~m}$ derived from the climate model mean and CLM4 are in close agreement with the ERA-Interim reanalysis data for the period 1986-2005. Under the RCP2.6, RCP4.5, and RCP8.5 scenarios, the soil temperature and active layer thickness experiences significant increases from 2006 to 2099 . Nearly half of the presentday permafrost at depths of $0-8 \mathrm{~m}$ in the QTEC may disappear before 2050 under the RCP 8.5 scenario.

Compared to the settlement hazard induced by climate warming alone, thermal settlement hazard can be delayed by approximately 17 years for a colder permafrost area based on the RCP8.5 scenario after taking remedial measures-the use of crushed-rock embankments in this case.
Despite employment of crushed rock embankments, nearly one-third of the region's grid cells can anticipate an ensemble mean timing of settlement prior to 2050 under the RCP8.5 scenario, which should be given more attention in future remediation planning. In addition, the validation of the predictions, based on observed soil temperature, lends credibility to the impending crisis posed by the hazard onset timing estimates.

Although these results may not necessarily reflect the actual timing of thermal settlement hazard in the QTEC, they do provide useful references for future engineering design and maintenance. In the present study, the use of ground ice from the map of permafrost and ground ice conditions, a coarse horizontal climate model resolution, and the absence of soil particle properties in calculations may have resulted in potential uncertainties. Therefore, an additional contribution of this study is to present a valuable method and to incite improved studies on this issue in the future. These studies may be based on fine ground ice data and high-resolution soil temperature output using the dynamical downscaling method.

Acknowledgments This research was jointly supported by the National Basic Research Program of China (2012CB955401) and the National Natural Science Foundation of China under Grants (41130103, 41421004, and 41405087). Thanks are due to the data centers for providing various data sets. The ERA-Interim reanalysis data were derived from the European Centre for Medium-Range Weather Forecasts (ECMWF), The CMIP5 simulation data were obtained from the Earth System Grid Federation (http://pcmdi9.1lnl. gov/), and the Tibetan Plateau frozen ground map was provided by the Cold and Arid Regions Sciences Data Center at Lanzhou (http:// westdc.westgis.ac.cn). We are indebted to Professor Qingbai Wu, Doctors Yanhu Mu, Zhongqiong Zhang, and Mingtang Chai for helpful discussions during preparation of this article. We are also indebted to the reviewers and editors for helpful comments and criticisms of the initial draft of this article.

Open Access This article is distributed under the terms of the Creative Commons Attribution 4.0 International License (http://crea tivecommons.org/licenses/by/4.0/), which permits unrestricted use, distribution, and reproduction in any medium, provided you give appropriate credit to the original author(s) and the source, provide a link to the Creative Commons license, and indicate if changes were made.

\section{References}

Bentsen, M., I. Bethke, J.B. Debernard, T. Iversen, A. Kirkevåg, Ø. Seland, H. Drange, C. Roelandt, I.A. Seierstad, C. Hoose, and J.E. Kristjansson. 2013. The Norwegian earth system model, NorESM1-M-Part 1: Description and basic evaluation of the physical climate. Geoscientific Model Development 6(3): $687-720$.

Brown, J., O.J. Ferrians Jr, J.A. Heginbottom, and E.S. Melnikov. 1997. Circum-Arctic map of permafrost and ground-ice conditions. U.S. Geological Survey in Cooperation with the CircumPacific Council for Energy and Mineral Resources, CircumPacific map series CP-45, scale 1:10,000,000, 1 sheet. 
Cheng, G.D. 2002. Interaction between Qinghai-Tibet Railway engineering and permafrost and environmental effects. Bulletin of the Chinese Academy of Sciences (1): 22-52 (in Chinese).

Cheng, G.D. 2003. Research on engineering geology of the roadbed in permafrost regions of Qinghai-Xizang Plateau. Quaternary Sciences 23(2): 134-141 (in Chinese).

Dee, D.P., S.M. Uppala, A.J. Simmons, P. Berrisford, P. Poli, S. Kobayashi, U. Andrae, M.A. Balmaseda, et al. 2011. The ERAInterim reanalysis: Configuration and performance of the data assimilation system. Quarterly Journal of the Royal Meteorological Society 137(656): 553-597.

Dunne, J.P., J.G. John, A.J. Adcroft, S.M. Griffies, R.W. Hallberg, E. Shevliakova, R.J. Stouffer, W. Cooke, et al. 2012. GFDL's ESM2 global coupled climate-carbon Earth System Models. Part I: Physical formulation and baseline simulation characteristics. Journal of Climate 25(19): 6646-6665.

Fu, X., and D. Zheng. 2000. Population growth and sustainable development in the Qinghai-Tibet Plateau. Resources Science 22(4): 22-29 (in Chinese).

Gao, X.J., M.L. Wang, and F. Giorgi. 2013. Climate change over China in the 21 st century as simulated by. Atmospheric and Oceanic Science Letters 6(5): 381-386.

Gent, P.R., G. Danabasoglu, L.J. Donner, M.M. Holland, E.C. Hunke, S.R. Jayne, D.M. Lawrence, R.B. Neale, et al. 2011. The community climate system model version 4 . Journal of Climate 24(19): 4973-4991.

Giorgetta, M.A., J. Jungclaus, C.H. Reick, S. Legutke, J. Bader, M. Böttinger, V. Brovkin, T. Crueger, et al. 2013. Climate and carbon cycle changes from 1850 to 2100 in MPI-ESM simulations for the coupled model intercomparison project phase 5 . Journal of Advances in Modeling Earth Systems 5(3): 572-597.

Guo, D.L., and H.J. Wang. 2011. The significant climate warming in the northern Tibetan Plateau and its possible causes. International Journal of Climatology 32(12): 1775-1781.

Guo, D.L., and H.J. Wang. 2013. Simulation of permafrost and seasonally frozen ground conditions on the Tibetan Plateau, 1981-2010. Journal of Geophysical Research: Atmospheres 118(11): 5216-5230.

Guo, D.L., and H.J. Wang. 2014. Simulated change in the nearsurface soil freeze/thaw cycle on the Tibetan Plateau from 1981 to 2010. Chinese Science Bulletin 59(20): 2439-2448.

Guo, D.L., and H.J. Wang. 2016. Comparison of a very-fineresolution GCM and RCM dynamical downscaling in simulating climate in China. Advances in Atmospheric Sciences. doi:10. 1007/s00376-015-5147-y.

Guo, D.L., M.X. Yang, and H.J. Wang. 2011a. Characteristics of land surface heat and water exchange under different soil freeze/thaw conditions over the central Tibetan Plateau. Hydrological Processes 25(16): 2531-2541.

Guo, D.L., M.X. Yang, and H.J. Wang. 2011b. Sensible and latent heat flux response to diurnal variation in soil surface temperature and moisture under different freeze/thaw soil conditions in the seasonal frozen soil region of the central Tibetan Plateau. Environmental Earth Science 63(1): 97-107.

Guo, D.L., H.J. Wang, and D. Li. 2012. A projection of permafrost degradation on the Tibetan Plateau during the 21st century. Journal of Geophysical Research 117(D5). doi:10.1029/ 2011JD016545.

James, W.H., M.M. Holland, P.R. Gent, S. Ghan, J.E. Kay, P.J. Kushner, J.-F. Lamarque, W.G. Large, et al. 2013. The community Earth system model: A framework for collaborative research. Bulletin of the American Meteorological Society 94(9): 1339-1360.

Koven, C.D., B. Ringeval, P. Friedlingstein, P. Ciais, P. Cadule, D. Khvorostyanov, G. Krinner, and C. Tarnocai. 2011. Permafrost carbon-climate feedbacks accelerate global warming.
Proceedings of the National Academy of Sciences 108(36): 14769-14774.

Koven, C.D., W.J. Riley, and A. Stern. 2013. Analysis of permafrost thermal dynamics and response to climate change in the CMIP5 Earth System Models. Journal of Climate 26(6): 1877-1900.

Lai, Y.M., L.X. Zhang, S.J. Zhang, and L. Mi. 2003. Cooling effect of ripped-stone embankments on Qinghai-Tibet Railway under climatic warming. Chinese Science Bulletin 48(6): 598-604.

Li, S., and G. Cheng. 1996. Map of permafrost distribution on the Qinghai-Xizang (Tibetan) Plateau, scale 1:3,000,000. Lanzhou: Gansu Cultural Press (in Chinese).

Liu, G., J. Zhang, and Q.B. Wu. 2006. Deformation characteristics and influential factors of subgrade in permafrost region. Highway 11: 23-26 (in Chinese).

Liu, M.H., Z.Z. Sun, F.J. Niu, G.L. Wu, and H.B. Yun. 2014. Variation characteristics of the permafrost along the QinghaiTibet Railway under the background of climate change. Journal of Glaciology and Geocryology 36(5): 1122-1130 (in Chinese).

Ma, W., Y.H. Mu, G.Y. Li, Q.B. Wu, Y.Z. Liu, and Z.Z. Sun. 2013. Responses of embankment thermal regime to engineering activities and climate change along the Qinghai-Tibet Railway. Scientia Sinica Terrae 43(3): 478-489 (in Chinese).

Ma, W., Z. Wen, Y. Sheng, Q. Wu, D. Wang, and W. Feng. 2012. Remedying embankment thaw settlement in a warm permafrost region with thermosyphons and crushed rock revetment. Canadian Geotechnical Journal 49(9): 1005-1014.

Nelson, F.E., O.A. Anisimov, and N.I. Shiklomanov. 2002. Climate change and hazard zonation in the circum-Arctic permafrost regions. Natural Hazards 26(3): 203-225.

Oleson, K.W., D.M. Lawrence, G.B. Bonan, M.G. Flanner, E. Kluzek, P.J. Lawrence, et al. 2010. Technical description of version 4.0 of the Community Land Model (CLM), NCAR Technical Note NCAR/TN-478+STR. Boulder, CO: National Center for Atmosphere Research.

Qin, Y.H., T.H. Wu, R. Li, C.W. Xie, Y.P. Qiao, H. Chen, D.F. Zou, and L. Zhang. 2015. Application of ERA product of land surface temperature in permafrost regions of Qinghai-Xizang Plateau. Plateau Meteorology 34(3): 666-675 (in Chinese).

Qiu, J. 2007. Environment: Riding on the roof of the world. Nature 449(7161): 398-402.

Ran, Y.H., X. Li, G.D. Cheng, T.J. Zhang, Q.B. Wu, H.J. Jin, and R. Jin. 2012. Distribution of permafrost in China: An overview of existing permafrost maps. Permafrost and Periglacial Processes 23(4): 322-333.

Ruan, G.F., J.M. Zhang, and M.T. Chai. 2014. Risk division of thaw settlement hazard along Qinghai-Tibet engineering corridor under climate change. Journal of Glaciology and Geocryology 36(4): 811-817 (in Chinese).

Seligman, B.J. 2000. Long-term variability of pipeline-permafrost interactions in north-west Siberia. Permafrost and Periglacial Processes 11(1): 5-22.

Slater, A.G., and D.M. Lawrence. 2013. Diagnosing present and future permafrost from climate models. Journal of Climate 26(15): 5608-5623.

Sun, Z.K., L.J. Wang, Q.C. Wei, and D.L. Min. 2004. Simulation and predication of temperature field of Qinghai-Tibet Railway roadbed on permafrost regions. Journal of Northern Jiaotong University 28(1): 55-59 (in Chinese).

Sun, Z.Z, W. Ma, and D.Q. Li. 2008. Ground temperature characteristics of block stone embankment and traditional embankment at Beiluhe along Qinghai-Tibet Railway. Chinese Journal of Geotechnical Engineering 30(2): 303-308.

Taylor, K.E., R.J. Stouffer, and G.A. Meehl. 2012. An overview of CMIP5 and the experiment design. Bulletin of the American Meteorological Society 93(4): 485-498. 
Tjiputra, J.F., C. Roelandt, M. Bentsen, D.M. Lawrence, T. Lorentzen, J. Schwinger, Ø. Seland, and C. Heinze. 2013. Evaluation of the carbon cycle components in the Norwegian Earth System Model (NorESM). Geoscitific Model Development 6: 301-325.

USNSIDC (U.S. National Snow and Ice Data Center). 2005. CircumArctic map of permafrost and ground ice conditions. http://nsidc. org/data/docs/fgdc/ggd318_map_circumarctic/index.html. Accessed 8 Dec 2015.

Wang, X.J., W.J. Mi, Y.L. Wei, and X.P. Wu. 2010. The change characteristics of the artificial upper limit of the roadbed and its relationship with the stability for Qinghai-Tibet Railway in the permafrost region. China Railway Science 31(5): 1-7 (in Chinese).

Watanabe, M., T. Suzuki, R. O'ishi, Y. Komuro, S. Watanabe, S. Emori, and Coauthors. 2010. Improved climate simulation by MIROC5: Mean states, variability, and climate sensitivity. Journal of Climate 23(23): 6312-6335.

Williams, P.J. 1986. Pipelines \& permafrost: Science in a cold climate. Don Mills, Ontario: Carleton University Press.

Wu, Q.B., and F.J. Niu. 2013. Permafrost changes and engineering stability in Qinghai-Xizang Plateau. Chinese Science Bulletin 58(10):1079-1094. doi:10.1007/s11434-012-5587-z.

Wu, Q.B., and C.J. Tong. 1995. Permafrost change and stability of Qinghai-Tibet Highway. Journal of Glaciology and Geocryology 17(4): 350-355 (in Chinese).

Wu, Q.B., and T.J. Zhang. 2008. Recent permafrost warming on the Qinghai-Tibetan Plateau. Journal of Geophysical Research 113(D13). doi:10.1029/2007JD009539.

Wu, Q.B., and T.J. Zhang. 2010. Changes in active layer thickness over the Qinghai-Tibetan Plateau from 1995 to 2007. Journal of Geophysical Research 115(D9). doi:10.1029/2009JD012974.

Wu, Q.B., B. Shi, and Y.Z. Liu. 2003. Study on interaction of permafrost and highway along Qinghai-Xizang Highway. Science in China Series D: Earth Sciences 46(6): 97-105.
Wu, Q.B., T.J. Zhang, and Y.Z. Liu. 2010. Permafrost temperatures and thickness on the Qinghai-Tibet Plateau. Global and Planetary Change 72(1-2): 32-38.

Xu, X.Z., J.C. Wang, and L.X. Zhang. 2010. Physics of frozen soil, 2nd edn. Beijing: Science Press (in Chinese).

Yang, M.X., F. Nelson, N. Shiklomanov, D.L. Guo, and G. Wan. 2010. Permafrost degradation and its environmental effects on the Tibetan Plateau: A review of recent research. Earth-Science Reviews 103(1): 31-44.

Yukimoto, S., Y. Adachi, M. Hosaka, T. Sakami, H. Yoshimura, M. Hirabara, T.Y. Tanaka, E. Shindo, et al. 2012. A new global climate model of the Meteorological Research Institute: MRICGCM3-model description and basic performance. Journal of the Meteorological Society of Japan 90A: 23-64.

Zhang, T., R.G. Barry, K. Knowles, J.A. Heginbottom, and J. Brown. 1999. Statistics and characteristic of permafrost and ground-ice distribution in the Northern Hemisphere. Polar Geography 23(2): 132-154.

Zhang, M.Y., Y.M. Lai, Z.H. Gao, and W. Yu. 2005. Influence of boundary conditions on the cooling effect of crushed-rock embankment in permafrost regions of Qinghai-Tibetan Plateau. Cold Regions Science and Technology 44(3): 225-239.

Zhang, J.M., D. Liu, and J. L. Qi. 2007. Estimation on the settlement and deformation of embankment along Qinghai-Tibet Railway in permafrost regions. China Railway Science 28(3): 12-17 (in Chinese).

Zhang, Z., and Q. Wu. 2012. Thermal hazards zonation and permafrost change over the Qinghai-Tibet Plateau. Natural hazards 61(2): 403-423.

Zhao, L. 2004. The freezing-thawing processes of active layer and changes of seasonally frozen ground on the Tibetan Plateau. Ph.D. dissertation, Cold and Arid Regions Environmental and Engineering Research Institute, Chinese Academy of Science, Beijing (in Chinese). 